ENTREPRENEURSHIP AND SUSTAINABILITY ISSUES

ISSN 2345-0282 (online) http://jssidoi.org/jesi/

2019 Volume 6 Number 3 (March)

http://doi.org/10.9770/jesi.2019.6.3(21)

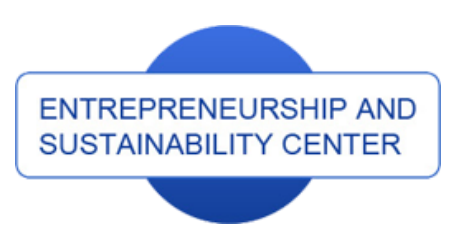

Publisher
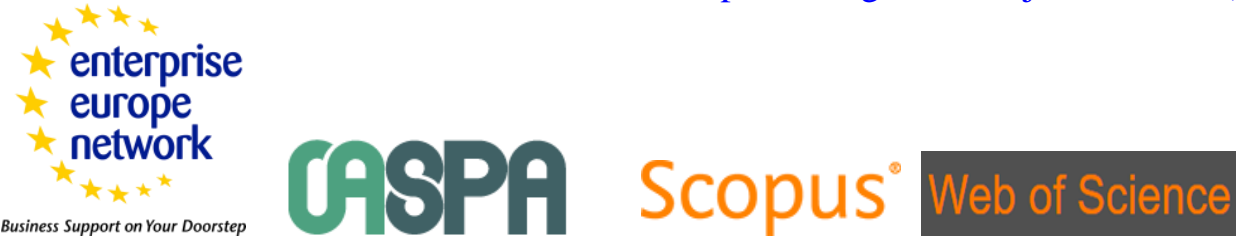

http://jssidoi.org/esc/home

1) Clarivate

\title{
MANAGEMENT CONTROL SYSTEM, CORPORATE SOCIAL RESPONSIBILITY, AND FIRM PERFORMANCE
}

\author{
Agus Ismaya Hasanudin ${ }^{\mathrm{a}}$, Yuliansyah Yuliansyah $^{\mathrm{b}}$, Jamaliah Said $^{\mathrm{c}}$, Christin Susilowati $^{\mathrm{d}}$, Muafi $^{\mathrm{e}}$
}

\author{
${ }^{a}$ Accounting Department, University of Tirtayasa, Indonesia \\ ${ }^{b}$ Accounting Department - University of Lampung, Indonesia \\ ${ }^{c}$ Accounting Research Institure - UiTM, Malaysia \\ ${ }^{d}$ Management Department, Universitas Brawijaya Malang, Indonesia \\ ${ }^{e}$ Management Department, Universitas Islam Indonesia
}

Corresponding author; muafi@uii.ac.id

Received 14 October 2018; accepted 10 December 2018; published 30 March 2019

\begin{abstract}
The aim of this study is to examine, through corporate reputation and double-loop learning, how Management Control System (MCS) in the form of a diagnostic and interactive system positively and significantly affects corporate social responsibility (CSR) and the firm performance (FP). This study uses a sample of 163 respondents who are middle to top level managers of manufacturing companies in Banten Province. We test hypotheses by using structural equation modelling, especially SmartPLS. We find that the effect of MCS on CSR does not directly affect the corporate firm performance, and that reputation and Double-Loop Learning (DLL) do mediate better firm performance. The study implies that MCS can help the company to support the process of CSR application more effectively when it matches performance to the expectation of stakeholders. In addition, manufacturers must maintain their reputation and increase their double-loop learning to seize opportunities as a result of their socially responsible activity, and to achieve optimal corporate firm performance.
\end{abstract}

Keywords: Management control system (MCS); corporate social responsibility (CSR); reputation (Rep); double-loop learning (DLL); firm performance (FP)

Reference to this paper should be made as follows: Hasanudin, A.I.; Yuliansyah, Y.; Said, J.; Susilowati, Ch.; Muafi. 2019. Management control system, corporate social responsibility, and firm performance, Entrepreneurship and Sustainability Issues 6(3): $1354-1368$. http://doi.org/10.9770/jesi.2019.6.3(21)

JEL Classifications: M10 


\section{ENTREPRENEURSHIP AND SUSTAINABILITY ISSUES}

ISSN 2345-0282 (online) http://jssidoi.org/jesi/

2019 Volume 6 Number 3 (March)

http://doi.org/10.9770/jesi.2019.6.3(21)

\section{Introduction}

Management control system (MCS) is a procedure and formal system that uses information to maintain the focus of participants in organizational activities such as planning, monitoring, and reporting (Henri, 2006). MCS can strengthen the resolve of businesspeople to operate socially and responsibly. Moreover, it can monitor whether the business operates in accordance with social responsibility and stakeholder interest (Durden, 2008). Although previous research (Arjalies and Mundy, 2013; Durden, 2008; Kiviverta, 2010) discusses the relation between MCS and corporate social responsibility (CSR), certain aspects have yet to be studied. Durden (2008) and Arjalies and Mundy (2013) use a qualitative method that causes difficulty in generalizing their findings due to the presence of specific organizational characteristics. Therefore, a quantitative study on the causal relation between MCS and CSR is needed so that the results can be generalized. Following up the limitations of the work of Durden (2008) and Arjalies and Mundy (2013), our quantitative approach measures the effect of MCS on CSR and the relationship of CSR to double-loop learning.

Earlier work on organizational education received by each individual in an organization to improve CSR activity discusses the effect of the learning process (Antal and Sobczak, 2005; Blackman et al., 2013), but few consider the opposite direction where CSR affects the learning process. Carter (2005) analyzes the role of organizational learning in mediating the relation between CSR and supplier performance but does not show clearly how CSR can affect organizational learning and what the mechanism of learning is. We use a new double-loop learning approach that is not found in previous discussions of CSR. According to Argyris (1976), double-loop learning is a process whereby an entity (an individual, a group, or an organization) is able to ask about fundamental changes in values, assumptions, and policies. This process is different from single-loop learning, which encourages entities to change only to reduce the difference between expected and obtained results (Argyris, 1976).

In double-loop learning, the learner not only searches for a way to act and reach a goal but also checks that the action itself is fit and proper. Double-loop learning involves reflection on values and norms and the social structure in which these values and norms are practiced. With the pattern of double-loop learning, each learner must have a more dynamic attitude towards change than with one-loop learning (Greenwood, 1998). Argyris (1976) added that an organization accustomed to the pattern of one-loop learning faces difficulty when changing current assumptions because double-loop learning is more dynamic in requiring such changes. Previous and system-wide CSR speeds the process of double-loop learning because the goals of and obstacles to CSR are already a familiar part of the learning process. Thus, if MCS can help to implement CSR, then double-loop learning will encourage employees to actively participate in CSR-related issues. The present study not only demonstrates the effect of CSR on double-loop learning but also explains how this process mediates the relation between CSR and corporate financial performance. A company's commitment to CSR improves its financial performance by reducing the costs of retention and access to capital (McGuire, Sundgren, and Schneeweis, 1988; Sweeney, 2009). However, the critics of this concept reject a direct link between CSR and the financial performance of a company (Mill, 2006; Moore, 2001).

No simple correlation exists between CSR and financial performance because a business benefit is necessary to bridge the relation (Fombrun, 2000). We show that double-loop learning mediates the relation of CSR and corporate financial performance. According to Kaplan and Norton (2000), double-loop learning is a powerful instrument that allows management to work as a team to interpret data and develop a new strategy in accordance with environmental change. Relating to the role of business benefit for bridging the relation of CSR and corporate financial performance (Fombrun, 2000), this study includes the second intervening variable for bridging that relation, which is reputation. Some earlier studies investigate the relation with contradictory results. Sweeney (2009) finds a positive direct relation between CSR and corporate financial performance with certain business benefits, while Mill (2006) finds that CSR has no relation to financial performance. 


\section{ENTREPRENEURSHIP AND SUSTAINABILITY ISSUES}

ISSN 2345-0282 (online) http://jssidoi.org/jesi/

2019 Volume 6 Number 3 (March)

http://doi.org/10.9770/jesi.2019.6.3(21)

According to Neville, Bell, and Mengüç (2005), the direct relation between CSR and performance is difficult to explain without a mediating variable, that is, reputation. Furthermore, reputation is a key factor in the success of a company. By promoting the outcome of corporate activity to the public, reputation connects CSR and performance (Neville, Bell, and Mengüç 2005). Thus, we include reputation as an intervening variable in the relation of CSR and performance and investigate the five-fold relationship between MCS, CSR, double-loop learning, the firm's reputation, and the firm's performance. In a 2012 survey conducted by the Program Peringkat Kinerja Perusahaan Dalam Pengelolaan Lingkungan Hidup or Ratings Program of Firm Performance in Environmental Management (PROPER), 24\% of manufacturing industries in the province of Banten in Indonesia scored "category red" in waste management. This category indicates the worst level of environmental management. The present study, which focuses on industries in Banten Province, contributes to the literature on MCS and CSR.

\section{Literature Review}

According to Durden (2008), MCS is able to accommodate the substantive phase of management action. He agrees with Kiviverta (2010) and argues that before disclosing sustainability in accordance with CSR external reporting, a company must be able to manage, measure, and monitor its own economic, social, and environmental performance (Durden, 2008). The company must measure employees' performance and motivate employees to achieve the CSR goal of their employer. The MCS implements CSR policy, and this implementation needs periodic examination. It changes in accordance with changes in the company's internal and external environment. Assumptions and policies that have been formed on the basis of those assumptions may or may not produce the planned results. Such policies may be realized in ways that are completely different from what has been planned.

Changes in a company's environment require each learner to learn quickly (Mundy, 2010). Double-loop learning in the context of organizational learning is not only an activity driven by a policy but is also a continuous test of the policy (Linz and Resch, 2010). According to Davison and Blackman (2005), employees develop a mental model or schema about their organization's CSR that will affect the way they see and react to events in the workplace. In other words, their logical thoughts on CSR become the basis of double-loop learning whereby any member of an organization can contemplate not only whether a deviation in the rules has occurred but also whether the rules must be changed to redefine "deviation" (Argyris, 1976). Double-loop learning can mediate and is hoped to "improve" corporate financial performance. According to Fombrun (2000), correlating CSR and financial performance in a simple way is difficult. A business benefit must exist to bridge the relation. That benefit is the knowledge acquired by employees as they relate double-loop learning to CSR, simultaneously increasing the effectiveness of MCS and the efficiency of the firm. Double-loop learning is known as a problemsolving technique in which the knowledge gained from contemplating anomalies triggers actions to achieve the company's goals, especially efficiency (Dooley, 1999).

Aside from double-loop learning, another business benefit is the CSR's credibility with stakeholders. Social responsibility underpins the firm's reputation, an idea common in the literature. The company that has its reputation for CSR confirmed in external reports shows steady long-term increases in performance (Adams, 2002). The company's reputation affects the prospective consumer's view of the entire corporate operation, including product quality, so they are willing to pay a premium price more than they will pay for a similar product generated by another firm (Sweeney, 2009).

Our framework relates to the MCS introduced by Durden (2008) and extended by Kiviverta (2010). We propose an additional new perspective where CSR can affect double-loop learning and where the concept becomes the intervening variable relating CSR to corporate financial performance. Then, adding an intervening variable, 
ENTREPRENEURSHIP AND SUSTAINABILITY ISSUES

ISSN 2345-0282 (online) http://jssidoi.org/jesi/

2019 Volume 6 Number 3 (March)

http://doi.org/10.9770/jesi.2019.6.3(21)

reputation, as a business benefit with double-loop learning bridges the relation of CSR and corporate financial performance. Figure 1 shows the model of the study.

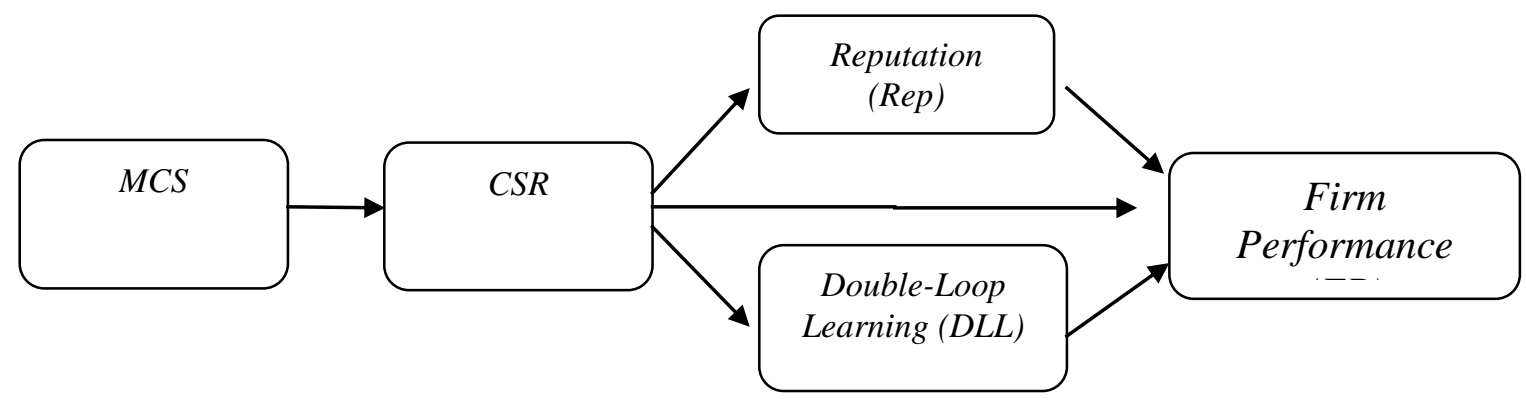

Figure 1. Research Model

In Figure 1, MCS positively affects CSR. Several previous studies have investigated the relation between MCS and CSR (Arjalies and Mundy, 2013; Durden, 2008). However, being only qualitative, those studies cannot measure the strength of the relationship. Thus, we use a quantitative method to find whether the relation between MCS and CSR is positive or negative and to measure it. Our first hypothesis (H1) is expressed below.

Furthermore, our second (H2) and third (H3) hypotheses posit that CSR affects reputation and double-loop learning positively. These two variables mediate the relation of CSR and corporate financial performance in our fourth (H4) and fifth (H5) hypotheses. Other researchers study the direct relation between CSR and corporate financial performance but with contradictory findings (Nadeem, 2012; Sweeney, 2009). Drawing a simple correlation between CSR and corporate financial performance is difficult, and a business benefit that can bridge the relation is needed (Fombrun, 2000). Our H2, H3, H4, H5, and H6 aim to determine whether CSR positively affects reputation and double-loop learning and whether any variable can mediate the relation between CSR and corporate financial performance.

\section{Hypothesis Development MCS and CSR}

According to Donaldson and Preston (1995), managers are responsible for selecting activities and using resources to obtain benefits for stakeholders. Durden (2008) also says that a resource-based view (RBV) confirms this important role for management, and an MCS must operate in accordance with the principles and goals of stakeholders. The RBV proposes that for an organization to reach its goal, its internal structure must adapt to external conditions. Internal resources are created and external market conditions are met through unique strategic development. According to Taghian (2008), in terms of marketing, a company's CSR is one of the intangible resources unique to the company. Galan (2006) argued that CSR is unique because it incorporates the formal values of the organizational culture. CSRs highlight the strategic role assignment of the existing MCS (Cresti, 2009). The mutual adaptation involves planning and control. Compensation and evaluation, incentive and benefit, are also present along with information sharing and cross-communication (Yuliansyah and Khan, 2015a; Yuliansyah and Khan, 2015b; Yuliansyah et al., 2016a). Consistent and socially oriented planning requires a control system whose objectives can be accurately measured. Only then can managers see whether or not the company achieves its objectives and can employees move in the right direction (Yuliansyah et al., 2017; Yuliansyah et al., 2016b).

$\mathrm{H}_{1}$. MCS positively affects CSR. 


\section{ENTREPRENEURSHIP AND SUSTAINABILITY ISSUES}

ISSN 2345-0282 (online) http://jssidoi.org/jesi/

2019 Volume 6 Number 3 (March)

http://doi.org/10.9770/jesi.2019.6.3(21)

\section{CSR and Reputation}

Stakeholder theory argues that a firm's performance is determined by its stakeholders' release of resources to trigger a response by the firm (Frooman, 1999). Furthermore, the customer's impression of the product depends not only on the quality, price, and unique selling points but also on the perceived social responsibility of the company to its stakeholders and to society (Fombrun and Shanley, 1990). In a competitive market environment, many companies use CSR to create a good corporate image (Jones, 1995). CSR is a key component of a firm's reputation (Sweeney, 2009), and a good reputation attracts profit, capital, and trading partners (Lai, 2010).

According to RBV theory, tangible resources increase the efficiency and effectiveness of intangible assets (Barney, 2001; Newbert, 2008). The reputation of a company is another intangible resource that is unique to the company and difficult to imitate; the reputation can continue to yield a competitive advantage for a long time (Fombrun and Shanley, 1990; Neville, 2005; Deephouse, 2000). By signaling high product quality, reputation allows a company to take a superior position in the market (Sweeney, 2009). Lai (2010) shows that CSR positively affects the corporate brand reputation. In addition, Sweeney (2009) shows CSR enhancing a firm's business and social reputation.

$\mathrm{H}_{2 .}$ CSR positively affects a firm's reputation.

\section{CSR and Double-loop Learning}

CSR can be a factor for organizational change, so management of that change should be considered (Kiviverta, 2010). Known and shared CSR in an organization reduces dissonance and strengthens motivation. Employees expect their organization to follow their mental model of CSR, and this condition affects the way they observe an event in the workplace and react to it (Davison and Blackman, 2005). CSR presumes that experience in the real world, and knowledge obtained through reflection results in mental model reframing, that is, learning and creating new knowledge (Davison and Blackman, 2005). Double-loop learning supports new knowledge that has not been learned before often with "unlearning" the "process by which firms eliminate old logic and make room for new ones" (Sinkula, 2002). In summary, CSR affects double-loop learning because people can contemplate changing the rules and not only learning how to fix deviations.

$\mathrm{H}_{3}$. CSR positively affects double-loop learning.

\section{Reputation and Corporate Financial Performance}

Deephouse (2000) defines corporate reputation as an overall media evaluation that is important to stakeholders. Pride and public reputation are crucial to the success of the company (Roberts and Dowling, 2002). According to Fombrun and Shanley (1990), a positive reputation inspires an organization to achieve competitive advantages that allow it to charge a premium and save promotion costs. According to the RBV, resources have value if they increase the efficiency and effectiveness of intangible assets (Newbert, 2007; 2008). Reputation based on effective CSR is difficult to imitate and therefore yields competitive advantages (Neville, 2005). According to Brammer and Millington (2005), a positive and significant relation exists between a firm's reputation and its corporate financial performance. In fact, Neville (2005) states that reputation is the mediating variable between CSR and financial performance.

$\mathrm{H}_{4}$. Reputation positively affects corporate financial performance.

\section{Double-loop Learning and Corporate Financial Performance}

The RBV posits that performance can be affected by how the organization manages its unique resources. One such resource is knowledge, and another is the ability to learn and quickly apply changes based on what is learned (Garvin, 1993). According to Barney (1991), knowledge and information unique to an organization allow for long-term planning that leads to higher corporate efficiency. The knowledge acquired by employees in doubleloop learning simultaneously increases process effectiveness and efficiency. One-loop learning focuses on routine activity. Double-loop learning manifests as problem solving, where new knowledge is triggered by anomalies and 


\section{ENTREPRENEURSHIP AND SUSTAINABILITY ISSUES}

ISSN 2345-0282 (online) http://jssidoi.org/jesi/

2019 Volume 6 Number 3 (March)

http://doi.org/10.9770/jesi.2019.6.3(21)

where people assume that the anomaly contains within itself the discoverable means to meet performance objectives and increase the efficiency of processes (Dooley, 1999). Thus, we present our fifth hypothesis:

$\mathrm{H}_{5}$. Double-loop learning positively affects corporate financial performance.

\section{CSR and Corporate Financial Performance}

Some researchers say that CSRs summarize the expectations of stakeholders, both internal and external, and increase the company's competitiveness in the long term (Webb, 2013). Jorgensen and Knudsen (2006) state that the entire area of the relation between CSR and a firm's performance is questionable. One study supports a light positive relation (Orlitzky, 2001). This relation has been recognized through financial performance mechanisms that are increased by CSR, but it has not been understood well. The RBV explains how to manage resources that are rare and difficult to imitate to achieve a competitive advantage (Barney, 1991). According to Taghian (2008), CSR can be a unique intangible resource for marketing. CSRs incorporate formal values of the firm's culture and Taghian (2008) argues that in the RBV, CSR is a unique intangible resource that is difficult to imitate and eventually leads to a competitive advantage. Other researchers conclude that the effect of CSR on financial performance is negative. The argument continues. The exact relation between CSR and financial performance is important and also difficult to pin down (McGuire and Sundgren, 1988).

$\mathrm{H}_{6}$. CSR positively affects corporate financial performance.

\section{RESEARCH METHOD}

\section{Population and Sample}

The population in this study consists of manufacturing companies located in Banten Province, Indonesia. We choose this population because, first, manufacturing industries have more complex control than other industries (Anthony and Govindarajan, 2007). Second, Banten Province accounts for $60 \%$ of all manufacturing companies in Indonesia. Moreover, manufacturing is the major industry in Banten Province, so waste management and industrial environmental issues have to be examined. Third, nearly a quarter (24\%) of manufacturing companies in Banten are in the red category, that is, the worst level of environmental management. Prior to questionnaire distribution, it was pretested to clarify understanding of the questions. Pretesting is conducted with companies that are similar but are outside the population area.

Data on manufacturing companies in Banten Province come from various sources, including the Ministry of Industry of Banten Province and the Statistics Centre Bureau. We sent questionnaires to the managers of those companies. We delivered a total of 300 questionnaires directly to 75 companies (see Table 1). A total of 163 respondents from 67 companies returned the questionnaires. Research data to test hypotheses were analyzed using structural equation model (SEM).

Table 1. Data Collection

\begin{tabular}{|l|c|}
\hline & Total \\
\hline Total questionnaires distributed & 300 \\
\hline Total questionnaires returned & 163 \\
\hline Response rate & $54.33 \%$ \\
\hline
\end{tabular}

\section{Measurement of Variables}

In the present study, MCS was measured using a two-dimensional construct of the diagnostic system and the interactive system adopted from Henri (2006). Then, CSR was measured using CSR activity affecting reputation and double-loop learning using the study instruments introduced by Sweeney (2009), that is, by evaluating the following: environmental friendliness, recycling of packaging material, production waste, information on labels, response to customer complaints, charity activities, job vacancies with an element of community support, a fair basic wage, and career development for employees. Firm reputation was measured using the study instruments of 


\section{ENTREPRENEURSHIP AND SUSTAINABILITY ISSUES}

ISSN 2345-0282 (online) http://jssidoi.org/jesi/

2019 Volume 6 Number 3 (March)

http://doi.org/10.9770/jesi.2019.6.3(21)

Neville (2005) and Sweeney (2009) on business reputation, performance, investment value, quality of products, service quality, management quality, environmental responsibility, and community responsibility. Measurement of double-loop learning emphasizes comprehensive thoughts on assumptions and beliefs (Cartwright, 2002). Feedback on an assumption creates a more effective back-and-forth decision-making process (Argyris, 1976). The functions of double-loop learning proposed by Kaplan and Norton (2000) for quantitative measurement are the following: working as a team to interpret data, development of new strategy, and adaptation to change. Finally, firm performance was measured using the variables used by Henri (2006) and Sweeney (2009), which are sales, net profit, and ratio of net profit to cost.

\section{RESULTS}

\section{Testing of Data Quality}

Validity Test

We test validity using partial least squares (PLS) software. Each construct with a value of average variance extracted (AVE) more than 0.5 can be said to have good discriminatory validity.

Table 2. Fornell-Lacker Criterion

\begin{tabular}{|l|l|l|l|l|l|}
\hline & MCS & CSR & DLL & Rep & FP \\
\hline MCS & 0.892 & & & & \\
\hline CSR & 0.972 & 0.926 & & & \\
\hline DLL & 0.925 & 0.930 & 0.868 & & \\
\hline Rep & 0.924 & 0.920 & 0.847 & 0.845 & \\
\hline FP & 0.934 & 0.928 & 0.937 & 0.867 & 0.916 \\
\hline
\end{tabular}

All variables have an AVE value of at least 0.845 , which is well above the 0.5 threshold for validity.

\section{Reliability Test}

We test reliability by considering the value of composite reliability from the indicator block measuring the construct. The result is satisfactory if it is above 0.7 .

Table 3. Cronbach's Alpha, Composite Reliability, AVE, R-squared

\begin{tabular}{|l|c|c|c|c|}
\hline & Cronbach's Alpha & $\begin{array}{l}\text { Composite } \\
\text { Reliability }\end{array}$ & AVE & R-squared \\
\hline MCS & 0.974 & 0.977 & 0.796 & 0.958 \\
\hline CSR & 0.979 & 0.982 & 0.753 & 0.865 \\
\hline DLL & 0.836 & 0.901 & 0.714 & 0.846 \\
\hline Rep & 0.866 & 0.909 & 0.840 & 0.904 \\
\hline FP & 0.905 & 0.940 & & 0.945 \\
\hline
\end{tabular}

As shown by the analysis result of reliability test with SmartPLS (Table 3), the value of composite reliability (column 3) has a minimum of 0.901 . This result means that the dependent variables (CSR, reputation, double-loop learning, and corporate financial performance) and the independent variable (MCS) have good reliability and internal consistency. 


\section{ENTREPRENEURSHIP AND SUSTAINABILITY ISSUES}

ISSN 2345-0282 (online) http://jssidoi.org/jesi/

2019 Volume 6 Number 3 (March)

http://doi.org/10.9770/jesi.2019.6.3(21)

\section{Results and Discussion}

Hypothesis 1 states that MCS positively affects CSR. $\mathrm{H}_{1}$ is accepted where MCS positively and significantly affects CSR. This relation is shown with estimation coefficient value between MCS and CSR of 0.980 and with a significance level of 11.196. The coefficient value of $R$-squared $\left(R^{2}\right)$ is 0.945 .

Table 4. Results for Inner Weights

\begin{tabular}{|l|c|c|c|c|}
\hline & $\begin{array}{c}\text { Original sample } \\
\text { estimate }\end{array}$ & $\begin{array}{c}\text { Mean of } \\
\text { subsamples }\end{array}$ & Standard deviation & T-statistic \\
\hline MCS -> CSR & 0.980 & 0.909 & 0.088 & 11.196 \\
\hline CSR -> Reputation & 0.966 & 0.853 & 0.149 \\
\hline CSR -> Double-Loop Learning (DLL) & 0.955 & 0.728 & 0.263 \\
\hline CSR -> Firm Performance (FP) & -0.055 & -0.060 & 0.206 & 3.636 \\
\hline Reputation (Rep) -> Firm Performance (FP) & 0.575 & 0.562 & 0.163 & 3.519 \\
\hline $\begin{array}{l}\text { Double-Loop Learning (DLL)-> Firm Performance } \\
\text { (FP) }\end{array}$ & 0.476 & 0.535 & 0.156 \\
\hline
\end{tabular}

As stated in $\mathrm{H}_{2}$, CSR positively affects a firm's reputation. This hypothesis is proven. The coefficient value between CSR and reputation is 0.966 with a significance level of 6.482 . The coefficient value of $\mathrm{R}^{2}$ is 0.846 . Thus, $\mathrm{H}_{2}$ is accepted. Hypothesis 3 shows that CSR positively affects double-loop learning. This premise is proven by a positive path coefficient value of 0.955 with a significance level of 3.636 and an $\mathrm{R}^{2}$ value of 0.865 . Our finding that $\mathrm{H}_{3}$ is supported. Hypothesis 4 states that reputation positively affects corporate financial performance. This hypothesis is proven by a positive path coefficient value of 0.575 with a significance level of 3.519. Thus, $\mathrm{H} 4$ is accepted. Hypothesis 5 indicates that double-loop learning positively affects corporate financial performance. This result is proven by an estimation coefficient value of 0.476 with a significance level of 3.056. The coefficient value of $\mathrm{R}^{2}$ is 0.904 . based on above data, H5 is accepted. Hypothesis 6 states that CSR positively affects corporate financial performance. We find a T-statistic value of only 0.270 . This value is below the t-count of 1.96 that is required to support the hypothesis. A negative effect is observed, but it is not significant. Therefore, we reject H6.

\section{Path Analysis}

\section{CSR Path Analysis of Firm Performance through Reputation}

To investigate the indirect effect of CSR on corporate financial performance, we consider the mediating variable reputation. Table 5 presents the path analysis. 


\section{ENTREPRENEURSHIP AND SUSTAINABILITY ISSUES}

ISSN 2345-0282 (online) http://jssidoi.org/jesi/

2019 Volume 6 Number 3 (March)

http://doi.org/10.9770/jesi.2019.6.3(21)

Table 5. CSR Path Analysis of Firm Performance through Reputation

\begin{tabular}{|l|l|l|l|l|l|}
\hline Path & Information & $\begin{array}{l}\text { Indirect Effect } \\
\text { CSR-Firm } \\
\text { Performance (FP) } \\
\text { (A) }\end{array}$ & $\begin{array}{l}\text { Direct Effect } \\
\text { CSR-Reputation } \\
(B)\end{array}$ & $\begin{array}{l}\text { Direct Effect } \\
\text { REP-Firm } \\
\text { Performance (C) }\end{array}$ & Indirect Effect A+ (BxC) \\
\hline 4 & CSR-Rep-FP & -0.055 & 0.966 & 0.575 & 0.500 \\
\hline
\end{tabular}

Based on the preceding calculation, the construct of reputation can mediate the effect of CSR on corporate financial performance. The comparison of direct and indirect effects shows that direct effect $(-0.055)<$ indirect effect $(+0.500)$.

\section{CSR Path Analysis toward Firm Performance through Double-Loop Learning}

To investigate the indirect effect of CSR on performance, we look at the addition of indirect effects through the mediating variable double-loop learning. Table 6 shows the path analysis.

Table 6. CSR Path Analysis of Firm Performance through Double-Loop Learning (DLL)

\begin{tabular}{|l|l|l|l|l|l|}
\hline Path & Information & $\begin{array}{l}\text { Direct Effect } \\
\text { CSR }- \text { FP } \\
(\mathrm{A})\end{array}$ & $\begin{array}{l}\text { Direct Effect } \\
\text { CSR-DLL } \\
(\mathrm{B})\end{array}$ & $\begin{array}{l}\text { Direct Effect } \\
\text { DLL-FP } \\
(\mathrm{C})\end{array}$ & Indirect Effect A + (BxC) \\
\hline 5 & CSR-DLL-FP & -0.055 & 0.955 & 0.476 & 0.399 \\
\hline
\end{tabular}

Based on the preceding calculation table, the construct of double-loop learning can mediate the effect of CSR on corporate financial performance. The comparison of direct and indirect effects shows that direct effect $(-0.055)<$ indirect effect (+0.399). The result of hypothesis testing of relations between MCS, CSR, reputation, double-loop learning, and corporate financial performance is presented in Table 7.

Table 7. Summary of Hypothesis Testing Results

\begin{tabular}{|l|l|l|}
\hline \multicolumn{1}{|c|}{ Hypothesis } & \multicolumn{1}{|c|}{ Hypothesis Statement } & Summary \\
\hline 1 & MCS positively affects CSR. & Accepted \\
\hline 2 & CSR positively affects reputation (Rep). & Accepted \\
\hline 3 & CSR positively affects double-loop learning (DLL). & Accepted \\
\hline 4 & Reputation (Rep) positively affects firm performance (FP). & Accepted \\
\hline 5 & Double-loop learning (DLL) positively affects firm performance (FP). & Accepted \\
\hline 6 & CSR positively affects firm performance (FP). & Not accepted \\
\hline
\end{tabular}

\section{Discussion}

The result of this study is in accordance with the two underlying theories: stakeholder theory and RBV. The stakeholder theory posits that an organization must be managed ethically to meet the identified needs of stakeholders (Freeman, 1984). Thus, management has to identify and satisfy each stakeholder before finalizing the CSR. In the RBV, the success of an organization is predicated on resources that are important, rare, or difficult to imitate. Focusing on the RBV forces basic changes both in the system and its strategic management to 


\section{ENTREPRENEURSHIP AND SUSTAINABILITY ISSUES}

ISSN 2345-0282 (online) http://jssidoi.org/jesi/

2019 Volume 6 Number 3 (March)

http://doi.org/10.9770/jesi.2019.6.3(21)

be able to create value (Barney, 1991; Wernerfelt, 1984). Then, CSRs incorporate the formal values of the company culture (Taghian, 2008). In addition, our study found that CSR positively affects a firm's reputation. This result supports the statement by Jones (1995) that in a highly competitive market environment, CSR responds to the expectations of various parties such as the media, public opinion, nongovernment organizations, and customers by creating a good corporate image. Lai (2010) also finds a positive and significant relation between CSR and reputation. The result of this study also supports the RBV that CSR is a unique resource that is very difficult to imitate and which incorporates formal values (Taghian, 2008). According to Neville (2005), reputation is also a resource formed from positive interaction with stakeholders and enhanced by selected information about the company's activity conveyed to stakeholders. Both statements clarify that CSR can affect a firm's reputation and that CSR is a resource wholly under the company's control.

Hypothesis 3 shows that CSR positively affects double-loop learning. Our findings strengthen the suggestion that any organization with CSR activity can use double-loop learning to foster individual sensitivity toward the dynamics of CSR in their organization. Mental models (schema) developed by employees will affect the way they view events in the workplace and then react to them (Davison and Blackman, 2005). The results of this study cannot be separated from the stakeholder theory and RBV. The stakeholder theory presupposes a framework for stakeholders to examine management practice (Mishra, 2013). Post and Preston (2002) add that successful management of stakeholders also involves learning because the characteristics of stakeholders change from time to time.

According to our study that reputation increases firm performance. The result of this study is in accordance with the findings of Neville (2005) and Sweeney (2009). A company that is considered socially responsible can benefit from its reputation, especially when its public image is boosted by publicity. In addition, its reputation in the business community increases its ability to attract capital and trading partners. Similarly, based on stakeholder theory from employees perspektive, the company management systematically attempts to produce benefits for each employee from learning, improved leadership, increased efficiency of working, employee commitment, and reduced costs. The higher the level of double-loop learning, the better the firm's performance (Dooley, 1999). Furthermore, the result of this study is in accordance with the RBV that performance is affected by the way of managing unique resources. One of these resources is knowledge, which includes the ability of an organization to apply changes based on what has been learned (Garvin, 1993).

\section{Conclusion And Limitations}

Our objective is to examine the effect of MCS on CSR and the effect of CSR on performance mediated by reputation and organizational learning. The present study specifically aims to examine the effect of MCS, including diagnostic control system and interactive control system, on CSR. This study also intends to examine the effect of CSR on reputation and double-loop learning as well as the effect of reputation and double-loop learning on corporate financial performance. Furthermore, this study aims to examine the direct effect of CSR on corporate financial performance and firm performance that is mediated by reputation and double-loop learning. To achieve the goal of the study, we conducted a survey by sending questionnaires to managers of manufacturing companies in Banten Province. Our primary data were the answers to the questionnaire collected from 163 respondents in 43 companies. Research data to test hypotheses were analyzed using SEM, particularly SmartPLS.

Referring to the result of data analysis, hypothesis testing, and discussion, we find the following: First, management control system in the form of a diagnostic and interactive system positively and significantly affects corporate social responsibility. This result shows that a company that has MCS based on performance gives high priority to the implementation of CSR as a strategy. Second, corporate social responsibility affects reputation and 


\section{ENTREPRENEURSHIP AND SUSTAINABILITY ISSUES}

ISSN 2345-0282 (online) http://jssidoi.org/jesi/

2019 Volume 6 Number 3 (March)

http://doi.org/10.9770/jesi.2019.6.3(21)

double-loop learning positively and significantly and facilitates such learning for company employees. Third, both reputation and double-loop learning have positive and significant effects on corporate financial performance. The process of knowledge creation through the double-loop learning model validates the legitimacy of the corporate reputation as an instrument to improve performance. Fourth, corporate social responsibility does not directly affect financial performance. This result indicates that CSR might be used as a strategy to determine the objective of social activity that will be conducted, but its role in increasing performance directly is unclear. Fifth, the indirect effect of CSR on corporate financial performance through reputation and double-loop learning means that CSR activity performed by the company becomes more effective in the form of financial performance if it is supported by business benefits such as reputation and double-loop learning.

This study has several practical implications. First, in designing social responsibility strategies for manufacturing companies, the MCS should focus on performance in the form of simultaneous diagnostics and interaction so that the MCS can help the company to achieve its CSR. Second, manufacturers must maintain their reputation and increase their double-loop learning to seize opportunities as a result of their socially responsible activity, and to achieve optimal corporate financial performance. Third, our definitive finding is that manufacturers should use corporate capabilities, such as double-loop learning, and corporate resources, such as reputation, simultaneously to improve performance.

This study has two limitations. First, it highlights performance measurements that implement MCS in the form of a diagnostic system and an interactive system operating in tandem. The synergy of these systems is expected to provide a maximum result. However, this study does not address how much relative attention should be given to diagnosis and interaction in assisting effective CSR implementation. Second, the empirical model built in this study uses only two of four levers in its levers of control framework. These are interactive and diagnostic. A future study that involves a four-lever framework might provide different results.

\section{References}

Adams, C. A. 2002. Internal organizational factors influencing corporate social and ethical reporting: Beyond current theorising. Accounting, Auditing \& Accountability. 15(2), 234-237. https://doi.org/10.1108/09513570210418905

Antal, A.B and Sobczak, A. 2005. Corporate Social Responsibility in France: A Mix of National Traditions and International Influences, Business \& Society, 46(1), 9-32, https://doi.org/10.1177/0007650306293391

Anthony, R. N., \& Govindarajan, V. 200). Management control systems (12th edn.). Boston: McGraw-Hill.

Argyris, C. 1976. Single-Loop and Double-Loop Models in Research on Decision Making. Administrative Science Quarterly 21(3): 363375. https://doi.org/10.2307/2391848/

Arjalies, D. L., and J. Mundy. 2013. The use of management control systems to manage CSR strategy: A levers of control perspective. Management Accounting Research 24(4), 284-300. https://doi.org/10.1016/j.mar.2013.06.003

Barney, J. B. 1991. Firms Resources and Sustained Competitive Advantage. Journal of Management, 17(1): 99-102. https://doi.org/10.1177/014920639101700108

Barney, J. 2001. Is the resource-based "view" a useful perspective for strategic management research? Yes, Academy of Management Review, 26(1), 41-56. https://doi.org/10.2307/259393

Blackman, D., Kennedy, M., and Quazi, A. 2012. Corporate social responsibility and individual resistance: Learning as the missing link in implementation, Management Learning, 44(3), 237-252, https://doi.org/10.1177/1350507612444392 


\section{ENTREPRENEURSHIP AND SUSTAINABILITY ISSUES}

ISSN 2345-0282 (online) http://jssidoi.org/jesi/

2019 Volume 6 Number 3 (March)

http://doi.org/10.9770/jesi.2019.6.3(21)

Brammer, S., and A. Millington. 2005. Corporate Reputation and Philanthropy: An Empirical Analysis. Journal of Business Ethics 61(1), 29-44. https://doi.org/10.1007/s10551-005-7443-4

Carter, C. R. 2005. Purchasing social responsibility and firm performance: The key mediating roles of organizational learning and supplier performance. International Journal of Physical Distribution \& Logistics Management 35(3), 177-194. https://doi.org/10.1108/09600030510594567

Cartwright, S. 2002. Double-Loop Learning: A Concept and Process for Leadership Educators. Journal of Leadership Education 1(1), 6871

Cresti, E. 2009. Sustainability Management Control Systems: Towards a Socially Responsible Planning and Control Framework. Paper read at Oxford Business \& Economics Conference Program, 24-6-2009, at UK.

Davison, G., and D. Blackman. 2005. The role of mental models in innovative teams. European Journal of Innovation Management, 8(4), 409-423. https://doi.org/10.1108/14601060510627795

Deephouse, D. L. 2000. Media Reputation as a Strategic Resource: An Integration of Mass Communication and Resource-Based Theories. Journal of Management 26(6):1091-1112. https://doi.org/10.1177/014920630002600602

Freeman, R.E. 1984. "Strategic Management: A stakeholder Approach”. Boston, MA: Pitman

Donaldson, T., and L. E. Preston. 1995. The Stakeholder Theory of the Corporation: Concepts, Evidence, and Implications. Academy of Management Review 20(1),70-73. https://doi.org/10.5465/amr.1995.9503271992

Dooley, J. 1999. Problem-Solving as a Double-Loop Learning System. Adaptive Learning Design. http://citeseerx.ist.psu.edu/viewdoc/summary?doi=10.1.1.35.44

Durden, C. 2008. Towards a socially responsible management control system. Accounting, Auditing \& Accountability Journal 21(5), 671694. https://doi.org/10.1108/09513570810872969

Fombrun, C.J., Gardberg, N.A., Sever, J.M. 2000. The Reputation Quotient: A Multi-Stakeholder Measure of Corporate Reputation. The Journal of Brand Management. 7(4), 241-255. https://doi.org/10.1057/bm.2000.10

Fombrun, C., and M. Shanley. 1990. What's in a Name? Reputation Building and Corporate Strategy. Academy of Management Journal 33 (2): 233-258. https://doi.org/10.5465/256324

Frooman, J. 1999. Stakeholder Influence Strategies, he Academy of Management Review, 24(2), 191-205 https://doi.org/10.2307/259074

Galan, J. L. 2006. Corporate social responsibility and strategic management. Journal of Management Studies 43(7), 1629-1630.

Garvin, D. A. 1993. Building a learning organization. Harvard Business Review 71(4):78-82. https://doi.org/10.1111/j.1467$\underline{6486.2006 .00655 . x}$

Greenwood, J. 1998. The role of reflection in single and double loop learning. Journal of Advanced Nursing 27(5), 1048-1053. https://doi.org/10.1046/j.1365-2648.1998.00579.x

Henri, J. F. 2006. Management control system and strategy: A resource-based perspective. Accounting, Organizations and Society 31(6), 529-558. https://doi.org/10.1016/j.aos.2005.07.001

Jaggi, B., and M. Freedman. 1992. An Examination of the Impact of Pollution performance on economic and market performance: pulp and paper firms. Journal of Business Finance \& Accounting 19(5), 699-704. https://doi.org/10.1111/j.1468-5957.1992.tb00652.x

Jones, T. M. 1995. Instrumental Stakeholder Theory: A Synthesis of Ethics and Economics. Academy of Management Review 20(2): 404437. https://doi.org/10.5465/amr.1995.9507312924

Jorgensen, A. L., and J. S. Knudsen. 2006. Sustainable competitiveness in global value chains: how do small Danish firms behave? Corporate Governance 6(4): 450-455. https://doi.org/10.1108/14720700610689568 


\section{ENTREPRENEURSHIP AND SUSTAINABILITY ISSUES}

ISSN 2345-0282 (online) http://jssidoi.org/jesi/ 2019 Volume 6 Number 3 (March)

http://doi.org/10.9770/jesi.2019.6.3(21)

Kaplan, R. S., and D. P. Norton. 2000. Double-Loop Management: Making Strategy a Continuous Process. Balance Scorecard Collaborative 2 (Harvard Business School Publishing), 1-4.

Kiviverta, V. 2010. Corporate Social Responsibility in Management Control Systems - Case Financial Services Industry in Finland. Master's Thesis, Accounting, Helsinki School of Economics, Finland.

Lai, C. S. 2010. The Effects of Corporate Social Responsibility on Brand Performance: The Mediating Effect of Industrial Brand Equity and Corporate Reputation. Journal of Business Ethics 95(3), 457-469. https://doi.org/10.1007/s10551-010-0433-1

Linz, A., and O. Resch. 2010. Double Loop Learning in Work based Settings. Berlin: Berlin School of Economics and Law.

McGuire, J. B.. A. Sundgren, A and Schneeweis, T. 1988. Corporate Social Responsibility and Firm Financial Performance. The Academy of Management Journal 31(4), 854-872. https://doi.org/10.5465/256342

Mill, G. 2006. The Financial Performance of a Socially Responsible Investment Over Time and a Possible Link with Corporate Social Responsibility. Journal of Business Ethics 63: 131-148. https://doi.org/10.1007/s10551-005-2410-7

Mishra, A. 2013. Application of Stakeholder Theory in Information Systems and Technology. Inzinerine Ekonomika-Engineering Economics. 24(3), 255-258. https://dx.doi.org/10.5755/j01.ee.24.3.4618

Moore, G. 2001. Corporate Social and Financial Performance: An Investigation in the UK Supermarket Industry. Journal of Business Ethics 34 (3/4), 299-315. https://doi.org/10.1023/A:1012537016969

Mundy. 2010. Creating dynamic tensions through a balanced use of management control system. Accounting, Organizations and Society 35 (5), 505-507. https://doi.org/10.1016/j.aos.2009.10.005

Nadeem, M. 2012. Impact of Corporate Social Responsibility on Financial Performance of Corporations: Evidence from Pakistan. $\begin{array}{lllllll}\text { International Journal } \quad \text { Learning } & \text { D } & \text { Development } & 2(6), & 107-118\end{array}$ http://citeseerx.ist.psu.edu/viewdoc/summary?doi=10.1.1.684.6856

Neville, B. A. Simon J. Bell, and Mengüç, B. 2005. Corporate reputation, statkeholders and the social performance-financial performance relationship. European Journal of Marketing 39(9/10), 1191-1193. https://doi.org/10.1108/03090560510610798

Newbert, S. L. 2007. Empirical research on the resource-based view of the firm: an assessment and suggestions for future research. Strategic Management Journal 28(2), 121-146. http://dx.doi.org/10.1002/smj.573

Newbert, S. L. 2008. Value, rareness, competitive advantage, and performance: a conceptual-level empirical investigation of the resourcebased view of the firm. Strategic Management Journal $29(7), \quad 745-768$. $\underline{\text { http://citeseerx.ist.psu.edu/viewdoc/similar?doi=10.1.1.465.2879\&type }=\text { sc }}$

Orlitzky, M. 2001. Corporate Social Performance and Firm Risk: A Meta-Analytic Review. Business \& Society 40(4), 373-377. https://doi.org/10.1177/000765030104000402

Post, J. E., and L. E. Preston. 2002. Managing the Extended Enterprise: The New Stakeholder View. California Management Review 45. https://doi.org/10.2307/41166151

Roberts, P. W., and G. R. Dowling. 2002. Corporate Reputation and Sustained Superior Financial Performance. Strategic Management Journal 23(12), 1079-1081. https://doi.org/10.1002/smj.274

Sinkula, J. M. 2002. Market-based success, organizational routines and unlearning. THe Journal of Business and Industrial Marketing 17 (4), 256-260. https://doi.org/10.1108/08858620210431660

Sweeney, L. 2009. A Study of Current Practice of Corporate Social Responsibility (CSR) and an Examination of the Relationship Between CSR and Financial Performance Using Structural Equation Modelling (SEM). Doctoral, Technology, Dublin, Ireland.

Taghian, M. 2008. Corporate social responsibility: a resource-based view of the firm. Paper read at ANZMAC 2008 Australian and New Zealand Marketing Academy Conference, at Olympic Park, Sydney. 


\section{ENTREPRENEURSHIP AND SUSTAINABILITY ISSUES}

ISSN 2345-0282 (online) http://jssidoi.org/jesi/

2019 Volume 6 Number 3 (March)

http://doi.org/10.9770/jesi.2019.6.3(21)

Webb, L. H. 2013. The Supply of Corporate Social Responsibility Disclosure among U.S Firms. SSRN 2007]. Available from http://ssrn.com/abstract $=970330$

Wernerfelt, B. 1984. A Resource-based View of the Firm. Strategic Management Journal 5(2): 171-180. https://doi.org/10.1002/smj.4250050207

Yuliansyah, A. B. Saputra, and L. Alvia. 2016a. The Leverage of Financing Performance Through Knowledge Sharing Using a System of Interactive Measurement of Performance. International Business Management 10(3), 200-208.

Yuliansyah, Y., B. Gurd, and N. Mohamed. 2017. The significant of business strategy in improving organizational performance. Humanomics 33 (1), 56-74. https://doi.org/10.1108/H-06-2016-0049

Yuliansyah, Y., and A. Khan. 2015a. Interactive use of performance measurement systems and the organization's customers-focused strategy: the mediating role of organizational learning. Problems and Perspectives in Management 13(2), 219-229.

Yuliansyah, Y., and A. A. Khan. 2015b. Strategic Performance Measurement System: A Service Sector And Lower Level Employees Empirical Investigation. Corporate Ownership and Control. 12 (3), 304-316.

Yuliansyah, Y., H. G. Rammal, and E. L. Rose. 2016b. Business Strategy \& Performance in Indonesia's Service Sector. Journal of Asia Business Studies 10(2), 164 - 182. https://doi.org/10.1108/JABS-07-2015-0094.

Short biographical note about the contributors at the end of the article (name, surname, academic title and scientific degree, duties, research interests):

Agus Ismaya HASANUDIN is senior lecturer in Accounting, Sultan Ageng Tirtayasa of Serang, Banten, Economic and Bussiness Faculty. Dr. Agus Ismaya Hasanudin, SE.,SH.,M.Si. obtained his Economic Doctoral Program in Accounting at the University of Diponogoro, Semarang, Indonesia in 2014. His research areas include Corporate Social Responsibility and Performance Organization. He has presented his international academic journal and can be contact at: ismayaagus@gmail.com

ORCID ID: 0000-0002-9389-6330

Jamaliah SAID is Assoc Professor at the Accounting Research Institute - Universiti Teknologi Mara - Malaysia. Dr Jamaliah completed her PhD in Accounting at the Universiti Teknologi Mara. Her areas of research interest include Management Accounting and Control, Managerial Accounting. She has published in several international academic journals and presented her research at reputed international conferences. Dr Jamaliah Said can be contacted at jamaliah533@salam.uitm.edu.my

ORCID ID: 0000-0003-1912-2529

Yuliansyah YULIANSYAH is Senior Lecturer in Accounting, University of Lampung, School of Economics and Business, Bandar Lampung, Indonesia.Dr Yuliansyah obtained his PhD in Accounting at the University of South Australia, Australia, in 2012. His research areas include management control system and strategy, strategic management accounting and performance measurement systems. He has presented his research in several conferences around the world and published widely in international academic journals. Dr Yuliansyah Yuliansyah is the corresponding author for this paper and can be contacted at: yuliansyah@ feb.unila.ac.id

ORCID ID: 0000-0002-0036-0853

Christin SUSILOWATI is currently a lecturer and researcher at Management Departament, Economic and Business Faculty of Brawijaya University Malang. Completed Doctoral Program from Brawijaya University Indonesia in 2010 and Master of Management Science from Airlangga University Indonesia in 2002. Her area of expertise is Strategic Management with interest in Strategic Human Resources Management, Marketing Management and Corporate Social Responsibility. The subject that she taught include Strategic Management, and Marketing Management.

ORCID ID: 0000-0002-1189-9221

MUAFI is currently a lecturer and researcher at the Universitas Islam Indonesia majoring in Management. He completed his Doctoral Program from Universitas Brawijaya in 2008 and his Master of Management Science from Universitas Airlangga in 1997. His area of expertise is in Human Resources Management with interest in Strategic Human Resource Management, Organisational Behavior, and Change Management. The subjects that he has taught include Strategic Human Resource Management, Strategic Management, and Oganisational Behaviour. He has secured a research grant from the Research and Technology Ministry and Dirjen Dikti Indonesia and Finance Ministry Indonesia. Muafi has owned some publication of indexed by Scopus and can be contact at: muafi@uii.ac.id

ORCID ID: 0000-0002-5078-4670 
ENTREPRENEURSHIP AND SUSTAINABILITY ISSUES

ISSN 2345-0282 (online) http://jssidoi.org/jesi/

2019 Volume 6 Number 3 (March)

http://doi.org/10.9770/jesi.2019.6.3(21)

Register for an ORCID ID:

https://orcid.org/register

Copyright (C) 2019 by author(s) and VsI Entrepreneurship and Sustainability Center

This work is licensed under the Creative Commons Attribution International License (CC BY).

http://creativecommons.org/licenses/by/4.0/

(c) (i) Open Access 